\title{
Maternal protein reserves and their influence on lactational performance in rats 2 . Effects of dietary protein restriction during gestation and lactation on tissue protein metabolism and $\mathrm{Na}^{+}, \mathrm{K}^{+}$-ATPase (EC 3.6.1.3) activity
}

\author{
BY A. P. PINE, N. S. JESSOP* AND G. F. ALLAN \\ Institute of Ecology and Resource Management, University of Edinburgh, West Mains Road, \\ Edinburgh EH9 $3 J G$ \\ AND J. D. OLDHAM \\ Genetics and Behavioural Science Department, Scottish Agricultural College, West Mains Road, \\ Edinburgh EH9 $3 J G$
}

(Received 3 March 1993-Revised 4 November 1993-Accepted 3 December 1993)

\begin{abstract}
Changes in tissue protein synthesis and an associated membrane transport system in rats were investigated during lactation and under conditions of dietary protein restriction. Following mating, female Sprague-Dawley rats (second parity) were caged individually and offered a high-protein diet (H; $215 \mathrm{~g}$ crude protein $(\mathrm{N} \times 6.25 ; \mathrm{CP}) / \mathrm{kg}$ dry matter $(\mathrm{DM}))$ ad lib. until day 12 of gestation. Subsequently half continued to receive diet $H$, whilst the remainder were offered a low-protein diet $(\mathrm{L} ; 65 \mathrm{~g} \mathrm{CP} / \mathrm{kg}$ DM) until parturition. On day 1 of lactation females were then allocated to either diet $H$ or another lowprotein diet $\left(\mathrm{L}_{2} ; 90 \mathrm{~g} \mathrm{CP} / \mathrm{kg} \mathrm{DM}\right)$ which were offered ad lib. until day 13 of lactation, giving four lactation groups $\mathrm{HH}, \mathrm{LH}, \mathrm{HL}_{2}$ and $\mathrm{LL}_{2}$. On days 1 and 13 of lactation groups of females were used in the estimation of tissue protein synthesis (flooding dose of $\left[{ }^{3} \mathrm{H}\right]$ phenylalanine) and $\mathrm{Na}^{+}, \mathrm{K}^{+}-\mathrm{ATPase}$ (EC 3.6.1.3) activity (polarographically) in skeletal muscle, mammary gland, liver and duodenal mucosa. By day 1 of lactation diet $\mathrm{L}$ had reduced fractional and absolute synthesis rates (FSR and ASR) of muscle protein $(P<0.05)$ and the $\mathrm{O}_{2}$ consumption associated with $\mathrm{Na}^{+}, \mathrm{K}^{+}$-ATPase, although not significantly $(P<0 \cdot 10)$. Rates of protein synthesis in the other tissues studied were not affected on day 1 of lactation by the gestation dietary treatment. By day 13 of lactation the feeding of diet $L_{2}$ had reduced muscle FSR and ASR of group $\mathrm{HL}_{2}$ to rates that were lower than those on day $1(P<0.05)$, comparable to those of group $L_{2}$ and lower than those of groups $\mathrm{HH}$ and $\mathrm{LH}(P<0.05)$. Diet $\mathrm{H}$ had allowed group LH to increase their muscle protein synthesis compared with that on day $1(P<0.05)$. Muscle $\mathrm{Na}^{+}, \mathrm{K}^{+}-$ ATPase activity on day 13 of lactation was also lower in groups offered diet $L_{2}(P<0.05)$. Mammary protein synthesis was increased during lactation with the feeding of diet $H(P<0.05)$, which was prevented by diet $L_{2}$ such that rates of groups $\mathrm{HL}_{2}$ and $\mathrm{LL}_{2}$ were lower than those of the two high-protein groups on day $13(P<0.01)$. Mammary respiration and in particular $\mathrm{Na}^{+}, \mathrm{K}^{+}-\mathrm{ATPase}$ activity was increased during lactation by the feeding of diet $H(P<0.05)$. Rates of protein synthesis and respiration in liver and duodenal mucosa were not significantly affected by the gestational or lactational dietary treatments. Calculated rates of muscle protein degradation suggest that whilst the loss of muscle protein in group $\mathrm{HL}_{2}$ during lactation might have been promoted by the decline in synthesis, the increase in degradation may have been quantitatively more important.
\end{abstract}

Lactation: Protein synthesis: $\mathrm{Na}^{+}, \mathrm{K}^{+}$-ATPase: Rat

When dietary protein is limiting, the extent of maternal protein reserve repletion at parturition has a significant impact on a female's ability to sustain lactation, with more

* For reprints. 
protein available for mobilization allowing an increased food intake and improved lactational performance (Mahan \& Mangan, 1975; Pine et al. 1994). Clearly loss of body protein occurs when the rate of degradation exceeds the rate of synthesis although, from the literature, it is not clear whether this is a result of a decrease in synthesis, an increase in breakdown or both (Siebrits et al. 1985; Vincent \& Lindsay, 1985; Sainz et al. 1986; Millican et al. 1987; Baracos et al. 1991).

In our earlier studies we did not make any measurements of tissue protein metabolism. A purpose of the work reported here was to explore the influence of feeding protein in gestation and in lactation on rates of protein synthesis in different tissues of the lactating rat. In the light of other work conducted in our laboratory (Friggens et al 1993) which described the relationships between dietary nutrient balance, food intake and lactational performance in rats, there was reason to think that a response to inadequate protein nutrition might be an elevation in metabolite energy expenditure by active tissues. As both protein synthesis and $\mathrm{Na}^{+}, \mathrm{K}^{+}$-ATPase $(E C$ 3.6.1.3) activity are two major energyrequiring processes (Milligan \& Summers, 1986), the protein synthesis measurements made here were augmented with studies of $\mathrm{Na}^{+}, \mathrm{K}^{+}$-ATPase activities.

\section{MATERIALS AND METHODS}

The experiment reported here adopted a similar experimental protocol to that reported in an earlier experiment (Pine et al. 1994) in which the effect on lactational performance of variations in the extent of maternal protein reserve repletion was investigated. The objective of the experimental protocol was to establish at parturition two groups of females that had distinct differences in the size of their maternal protein mass and, thus, reserves. The experimental protocol is described in detail below.

\section{Experimental design}

Forty-four, second parity, female Sprague-Dawley rats (Harlan and Olac UK Ltd., Shaws Farm, Bicester, Oxon.) weighing on average 302.3 (SE 2.1) g were caged individually in a room regulated at $22^{\circ}$ and relative humidity from $40-60 \%$, under a $12 \mathrm{~h}$ light-dark cycle with the light period from $08.00-20.00$ hours. For mating the females were placed, at the appropriate time, individually in a wire-bottomed cage with a proven male breeder. The morning on which mating was confirmed, through the presence of vaginal plugs, was designated day 1 of gestation and the females were returned to solid-bottomed plastic cages for the remainder of the experiment.

Following mating the females were offered a high-protein diet $(\mathrm{H}, 215 \mathrm{~g}$ crude protein $(\mathrm{N} \times 6.25 ; \mathrm{CP}) / \mathrm{kg}$ dry matter (DM) (Table 1) ad lib. until day 12 of gestation. Subsequently half of the females continued to receive the high-protein diet while the remainder were offered a low-protein diet ( $\mathrm{L}, 65 \mathrm{~g} \mathrm{CP} / \mathrm{kg} \mathrm{DM})$ ad lib. until parturition. Immediately following parturition four groups of females were selected for slaughter, two groups to be used in carcass analysis $(n 4)$ while the other two groups $(n 6)$ were used in the analysis of tissue metabolism (protein synthesis and $\mathrm{Na}^{+}, \mathrm{K}^{+}$-ATPase activity).

On day 1 of lactation the remaining females were allocated factorially to either diet $\mathrm{H}$ or another low-protein diet $\left(\mathrm{L}_{2}, 90 \mathrm{~g} \mathrm{CP} / \mathrm{kg} \mathrm{DM}\right)$ which was then offered ad lib. for the remainder of the experiment. This dietary allocation produced four groups of females $(\mathrm{HH}$, $\mathrm{HL}_{2}$, LH and $\mathrm{LL}_{2}$, the first letter representing the dietary treatment from day 12 of gestation and the second letter representing the lactation diet) that reached day 13 of lactation, on which all females and litters were slaughtered and measurements of maternal tissue metabolism were made.

All diets were formulated to provide approximately $21 \mathrm{MJ}$ gross energy (GE)/kg DM with a constant carbohydrate : fat ratio of $2 \cdot 4: 1$. All litters were standardized to twelve pups 
Table 1. Composition of high- and low-protein diets $(\mathrm{g} / \mathrm{kg}$ dry matter $(D M))$

\begin{tabular}{lccc}
\hline \hline Diet... & High-protein $(\mathrm{H})$ & Low-protein (L) & Low-protein $\left(\mathrm{L}_{2}\right)$ \\
\hline Casein* & 215 & 65 & 90 \\
Starch-sucrose $\dagger$ & 439 & 542 & 525 \\
Vegetable fat & 196 & 243 & 235 \\
Vitamin mix $\neq$ & 50 & 50 & 50 \\
Mineral mix & 100 & 100 & 100 \\
Diet analysis: & 212 & 63 & 88 \\
$\quad$ Protein (g CP/kg DM) & $21 \cdot 7$ & $21 \cdot 5$ & 21.7 \\
$\quad$ GE (MJ/kg DM) & 0.01 & 0.01 & 0.01 \\
Antioxidant (butylated & & & \\
hydroxytoluene; g/kg fresh wt) & & & \\
\hline \hline
\end{tabular}

$\mathrm{CP}$, crude protein $(\mathrm{N} \times 6.25) ; \mathrm{GE}$, gross energy.

* Casein supplemented with DL-methionine $(99: 1, \mathrm{w} / \mathrm{w})$.

$\dagger$ Starch-sucrose mixture $(2 ; 1, w / w)$.

$\ddagger$ Vitamin and mineral mixes were formulated to meet requirements of the National Research Council (1978).

on day 1 of lactation to maximize the lactational stress imposed. This was achieved by removal or cross fostering of pups from one litter to another. In our experience females who had successfully raised a previous litter would accept additional pups whereas with primiparous females this was more difficult to achieve. Litter weights were recorded daily throughout lactation. Dam body weights and food intakes were recorded throughout the experiment. All females were given free access to drinking water.

\section{Measurement of protein synthesis}

On either day 1 or 13 of lactation, rates of total protein synthesis were measured in vivo in the mammary gland, liver, gastrocnemius muscle and duodenal mucosa using the floodingdose technique of Garlick et al. (1980).

Between 09.00 and 13.00 hours dams were injected via a lateral tail vein with a solution containing $150 \mathrm{mmol} \mathrm{L}$-phenylalanine $/ 1$ and $1.85 \mathrm{MBq} \mathrm{L-}\left[2,6-{ }^{3} \mathrm{H}\right]$ phenylalanine $/ \mathrm{ml}$ (Amersham International Ltd., Bucks) at $10 \mathrm{ml} / \mathrm{kg}$ body weight and returned to their litters. After $10 \mathrm{~min}$ dams were decapitated and samples of the left inguinal abdominal mammary gland, liver, gastrocnemius muscle and duodenal mucosa were quickly excised and plunged into liquid $\mathrm{N}_{2}$. A sample of mucosa was obtained by opening a length of duodenum, washing with ice-cold saline $(9 \mathrm{~g} \mathrm{NaCl} / 1)$ and scraping with a microscope slide. In the present study the gastrocnemius muscle was used because it is thought to be a good indicator of the response of the body's musculature to dietary treatment (Waterlow et al. 1978). Samples of tissue were used to measure fractional synthesis rate (FSR) of total tissue protein from the incorporation of $\left[{ }^{3} \mathrm{H}\right]$ phenylalanine into tissue protein. Correction for the gradual linear decline of specific activity of tissue free phenylalanine during the $10 \mathrm{~min}$ incorporation period was ignored because of the previous observation that the rate of decline in mammary tissue, liver and muscle is slow and insignificant (Garlick et al. 1983; Sampson et al. 1986). Calculation of FSR (\%/d) uses the formula:

$$
\mathrm{FSR}=\frac{\mathrm{S}_{\mathrm{B}} \times 100}{\mathrm{~S}_{\mathrm{A}} \times \mathrm{t}}
$$

where $S_{B}$ and $S_{A}$ are specific activities of protein-bound and free phenylalanine respectively, and $t$ is the time in days that elapsed between injection and rapid cooling of tissue. Absolute 
synthesis rates (ASR) are calculated from FSR and tissue protein content. Tissue RNA concentration was measured as described by Munro \& Fleck (1969), with muscle RNA calculated using the equation of Ashford \& Pain (1986), and tissue protein concentration measured with the method of Lowry et al. (1951) using bovine serum albumin as a standard.

\section{Measurement of $\mathrm{Na}^{+}, \mathrm{K}^{+}$-ATPase activity}

The tissue activity of the enzyme $\mathrm{Na}^{+}, \mathrm{K}^{+}$-APase on days 1 and 13 of lactation was estimated through measurements of the inhibition of tissue $\mathrm{O}_{2}$ consumption caused by the addition of ouabain, a specific inhibitor of the $\mathrm{Na}^{+}, \mathrm{K}^{+}$-ATPase enzyme (Albers et al. 1968), to the incubation medium. Ouabain concentrations of $1 \mu \mathrm{mol} / 1$ or greater have been shown to give maximal inhibition of $\mathrm{Na}^{+}, \mathrm{K}^{+}$-ATPase-associated respiration (Gregg \& Milligan 1982a).

$\mathrm{O}_{2}$ consumption rates were measured polarographically using an oxygen electrode (Rank Bros., Cambridge). Weighed samples of liver snips, mammary gland slices $(20 \mu \mathrm{m})$; (Bartley \& Abraham, 1976), muscle fibre bundles (tied with sutures; Gregg \& Miligan, 1982b) and duodenal mucosal scrapes were washed and placed in an oxygen electrode chamber in $3 \mathrm{ml}$ Minimal Essential Medium (MEM; Sigma Chemical Co. Ltd, Poole, Dorset) containing $5 \mathrm{mmol} \mathrm{Hepes} / 1$ at $37^{\circ}, \mathrm{pH} \mathrm{7.4}$, and the $\mathrm{O}_{2}$ consumption was recorded for 10-15 min. After this time ouabain was added to a final concentration of $10^{-4} \mathrm{~mol} / 1$ and the $\mathrm{O}_{2}$ consumption was recorded for a further $10 \mathrm{~min}$. The difference between the initial $\mathrm{O}_{2}$ consumption and that following ouabain treatment was termed the $\mathrm{Na}^{+}, \mathrm{K}^{+}$-ATPasedependent respiration. The percentage inhibition of the original $\mathrm{O}_{2}$ consumption associated with $\mathrm{Na}^{+}, \mathrm{K}^{+}$-ATPase activity was calculated using the ratio of $\mathrm{Na}^{+}, \mathrm{K}^{+}$-ATPase dependent respiration to the initial $\mathrm{O}_{2}$ consumption. The size of the piece of tissue used was such that the reduction in the $\mathrm{O}_{2}$ content of the incubation medium during the $20-25$ min procedure was never greater than $25 \%$ of its initial value.

\section{Carcass analysis}

For the groups selected for carcass analysis on day 1 of lactation, dams were killed by decapitation and their carcass, liver, mammary gland and gastrointestinal tract were dissected and analysed for dry matter, protein, ash and fat. The procedures used for these analyses have been described elsewhere (Pine et al. 1994).

\section{Statistical analysis}

For statistical treatment of the results two-way analysis of variance and one-way analysis of variance were used and, where appropriate by calculation of least significant differences, $t$-test were used to compare sample means between diets and stages of lactation. To establish the impact that the gestation treatments had on the extent of maternal protein reserve repletion at parturition, the carcass composition values for dams slaughtered on day 1 of lactation were amalgamated with those for rats from a parallel experiment (Pine et al. 1994) and treated similarly during lactation.

\section{RESULTS}

Food intakes and body weight changes during gestation

The food intakes, body weight and carcass composition changes, mean pup birth weights and pups/litter of females offered diets $\mathrm{H}$ or $\mathrm{L}$ during gestation are shown in Table 2. Feeding low-protein diet during the second half of the gestation did not significantly affect food intake or maternal gestation weight gain compared with females offered the high- 
Table 2. Maternal body weight gain, carcass composition, food intakes and pup birth weight of rats given either high $(H)$ - or low $(L)$-protein diets during gestation $\dagger$

\begin{tabular}{|c|c|c|c|}
\hline Diet... & $\underset{(n 21)}{\mathrm{H}}$ & $\begin{array}{c}\mathrm{L} \\
(n 21)\end{array}$ & SD \\
\hline Dam wt gain $(\mathrm{g})$ & $12 \cdot 0$ & $3 \cdot 3$ & $19 \cdot 5$ \\
\hline $\begin{array}{l}\text { Food intake (g DM), days } 1-11 \text { of gestation } \\
\text { Food intake (g DM), day } 11-\text { parturition }\end{array}$ & $\begin{array}{c}193 \cdot 8 \\
182 \cdot 3\end{array}$ & $\begin{array}{l}193.8 \\
186.8\end{array}$ & $\begin{array}{l}16 \cdot 7 \\
24 \cdot 8\end{array}$ \\
\hline $\begin{array}{l}\text { Carcass composition } \neq \text {, day } 1 \text { of lactation: } \\
\text { Protein }(\mathrm{g}) \\
\text { Fat }(\mathrm{g}) \\
\text { Abdominal Fat }(\mathrm{g})\end{array}$ & $\begin{array}{l}43 \cdot 5 \\
22 \cdot 8 \\
19 \cdot 6\end{array}$ & $\begin{array}{l}38 \cdot 7^{* *} \\
23 \cdot 5 \\
21 \cdot 1\end{array}$ & $\begin{array}{l}3 \cdot 6 \\
5 \cdot 8 \\
6 \cdot 1\end{array}$ \\
\hline $\begin{array}{l}\text { Mammary wt§ }(\mathrm{g}) \\
\text { Protein }(\mathrm{g}) \\
\text { Fat }(\mathrm{g})\end{array}$ & $\begin{array}{r}15 \cdot 0 \\
1 \cdot 6 \\
5 \cdot 5\end{array}$ & $\begin{array}{r}14 \cdot 3 \\
1 \cdot 4 \\
6 \cdot 2\end{array}$ & $\begin{array}{l}4 \cdot 2 \\
0 \cdot 3 \\
2 \cdot 1\end{array}$ \\
\hline $\begin{array}{l}\text { Liver wt§ (g) } \\
\text { Protein }(\mathrm{g}) \\
\text { Fat }(\mathrm{g})\end{array}$ & $\begin{array}{r}11 \cdot 2 \\
2 \cdot 2 \\
0 \cdot 9\end{array}$ & $\begin{array}{r}10 \cdot 7 \\
1 \cdot 9 \\
1 \cdot 1\end{array}$ & $\begin{array}{l}1 \cdot 4 \\
0 \cdot 2 \\
0 \cdot 3\end{array}$ \\
\hline $\begin{array}{l}\text { Gastrointestinal tract } w t \S(g) \\
\text { Protein }(\mathrm{g}) \\
\text { Fat }(\mathrm{g})\end{array}$ & $\begin{array}{l}7 \cdot 9 \\
1 \cdot 1 \\
1 \cdot 0\end{array}$ & $\begin{array}{l}8 \cdot 2 \\
1 \cdot 2 \\
1 \cdot 3\end{array}$ & $\begin{array}{l}1.6 \\
0.2 \\
0.7\end{array}$ \\
\hline $\begin{array}{l}\text { Litter size (pups/litter) } \\
\text { Mean pup birth wt (g) }\end{array}$ & $\begin{array}{r}12 \cdot 8 \\
5 \cdot 7\end{array}$ & $\begin{array}{r}11 \cdot 9 \\
5 \cdot 4\end{array}$ & $\begin{array}{l}3 \cdot 2 \\
0 \cdot 8\end{array}$ \\
\hline
\end{tabular}

DM, dry matter.

Mean value was significantly different from that of the high-protein group: ${ }^{* *} P<0.01$.

$\dagger$ For details of diets and procedures, see Table 1 and pp. 182-184.

$\$$ Composition estimated using data from Pine et al. (1994): H, $n$ 8; L, $n 7$.

$\S \mathrm{H}, n 4 ; \mathrm{L}, n 4$.

protein diet. The low-protein dietary treatment also did not impair fetal development, and the mean pup birth weight and litter size (pups/litter) did not differ between the two treatment groups.

In order to provide a stronger indication of the extent of maternal protein reserve repletion at parturition the effects of the gestation dietary treatments on the carcass composition of females slaughtered on day 1 of lactation were estimated using data from two parallel experiments. From Table 2 it can be seen that the feeding of the low-protein diet during the second half of gestation had reduced $(P<0.01)$ the carcass protein content and thus protein reserves of group $L$, while having no significant effect on the size of their carcass and abdominal fat stores. The gestation dietary treatment had therefore the desired effect of ensuring that females at parturition had variations in the size of their protein reserve.

Dietary protein restriction during gestation also had no significant effect on the size and composition of the mammary gland, liver and gastrointestinal tract on day 1 of lactation.

\section{Effects of the gestational and lactational dietary treatments on dam food intakes, body weight changes and litter weight gains during lactation}

The results for the four lactation groups $\mathrm{HH}, \mathrm{LH}, \mathrm{HL}_{2}$ and $\mathrm{LL}_{2}$ are shown in Table 3 . The changes in maternal body weight during lactation were significantly affected only by the lactational dietary treatment. All four groups lost weight, but the feeding of the low-protein diet resulted in a greater weight loss $(P<0.05)$, although the weight losses by groups $\mathrm{HL}_{2}$ 
Table 3. Body weight loss, food intake and litter weight gain during days 1-13 of lactation of rats offered either high $(H)$ - or low $(L)$-protein diets during gestation $(G e)$ and then $H$ or $a$ different low $\left(L_{2}\right)$-protein diet during lactation $(L a) \dagger$

\begin{tabular}{|c|c|c|c|c|c|c|c|c|}
\hline \multirow{2}{*}{ Diet sequence... } & \multirow{2}{*}{$\begin{array}{c}\mathrm{HH} \\
(n 6)\end{array}$} & \multirow{2}{*}{$\begin{array}{c}\mathrm{LH} \\
(n 5)\end{array}$} & \multirow{2}{*}{$\begin{array}{l}\mathrm{HL}_{2} \\
(n 6)\end{array}$} & \multirow{2}{*}{$\begin{array}{l}\mathbf{L L}_{2} \\
(n 6)\end{array}$} & \multirow[b]{2}{*}{ SD } & \multicolumn{3}{|c|}{$\begin{array}{l}\text { Statistical significance } \\
\text { of diet effects }\end{array}$} \\
\hline & & & & & & $\mathrm{Ge}$ & $\mathbf{L a}$ & $\mathrm{Ge} \times \mathrm{La}$ \\
\hline Dam wt change $(g / 12 d)$ & $-17 \cdot 4$ & -6.6 & $-63 \cdot 1$ & $-51 \cdot 6$ & $28 \cdot 0$ & NS & $* *$ & NS \\
\hline Food intake (g DM/12d) & 337 & 293 & 257 & 227 & $53 \cdot 5$ & $*$ & $* * *$ & NS \\
\hline Days $1-6$ (g DM) & 130 & 103 & 127 & 105 & 19.5 & $* *$ & NS & NS \\
\hline Days $7-13(\mathrm{~g} \mathrm{DM})$ & 207 & 190 & 130 & 122 & $45 \cdot 6$ & NS & $* * *$ & NS \\
\hline Litter wt gain $(\mathrm{g} / 12 \mathrm{~d})$ & 194 & 153 & 94 & 69 & $52 \cdot 5$ & $* * *$ & $* * *$ & NS \\
\hline Days $1-6$ & 82 & 52 & 52 & 32 & 21.6 & $* * *$ & $* * *$ & NS \\
\hline Days $7-13$ & 112 & 101 & 42 & 37 & $35 \cdot 2$ & $*$ & $* * *$ & NS \\
\hline
\end{tabular}

DM, Dry matter; NS, not significant.

$* \quad P<0.05, * * P<0.01, * * * P<0.001$.

$\dagger$ For details of diets and procedures, see Table 1 and pp. 182-184.

and $\mathrm{LL}_{2}$ were not significantly different and this reflects their similar weight gains during gestation. The weight losses of the two high-protein groups also did not differ.

The food intakes of the four treatment groups were influenced by both gestational and lactational dietary treatments. The total food intake (g DM/12 d) of diet $\mathrm{H}$ by group $\mathrm{LH}$ was less than that of group HH $(P<0.05)$ due to the lower intake of group LH during the first six days $(P<0.05)$. Both groups $\mathrm{HH}$ and $\mathrm{LH}$ showed a considerable increase in food intake between the two halves of lactation. The feeding of diet $\mathrm{L}_{2}$ during lactation resulted in a suppression $(P<0.05)$ in total food intake of groups $\mathrm{HL}_{2}$ and $\mathrm{LL}_{2}$ when compared with group $\mathrm{HH}$ and was greatest for group $\mathrm{LL}_{2}$; intake by group $\mathrm{LL}_{2}$ being lower $(P<0.05)$ than that for group $\mathrm{HL}_{2}$ during the first $6 \mathrm{~d}$ and the whole $12 \mathrm{~d}$ period. During the first half of lactation the DM intake of diet $\mathrm{L}_{2}$ by group $\mathrm{HL}_{2}$ was greater than that of group LH $(P<0.05)$ but not that of group HH. During the second half of lactation intakes of both high groups had increased sufficiently to be greater than that of $\mathrm{HL}_{2}(P<0.05)$.

Lactational performance was estimated by the weight gain of a standardized litter and was influenced by both gestation and lactation dietary treatments. The lactational performance of group LH was less $(P<0.05)$ than that of group $\mathrm{HH}$, reflecting the difference in their intakes of diet $\mathbf{H}$. For groups $\mathbf{H H}$ and $\mathbf{L H}$, litter weight gain increased between the two halves of lactation, again reflecting the considerable increase in food intake. Dietary protein restriction significantly impaired the litter weight gain of groups $\mathrm{HL}_{2}$ and $\mathrm{LL}_{2}$ when compared with $\mathrm{HH}$ and $\mathrm{LH}$. However, the lactational performance of the low-protein groups was influenced by their gestation dietary treatment, with group $\mathrm{LL}_{2}$ having a lower litter weight gain (total and first $6 \mathrm{~d}$ ) than group $\mathrm{HL}_{2}(P<0.01)$. The greater performance of Group $\mathrm{HL}_{2}$ during the first half of lactation was supported by their greater food intake and maternal protein reserves, and allowed them to achieve a similar lactational performance to that of group $\mathrm{LH}$. Despite this, group $\mathrm{HL}_{2}$ was unable to maintain this greater performance and their rate of litter weight gain was reduced by $20 \%$ during the second half of lactation.

\section{Effect of gestational dietary treatment on tissue protein synthesis on day 1 of lactation}

Rates of protein synthesis and tissue composition for the gastrocnemius muscle, mammary gland, liver and duodenal mucosa for females offered diet $\mathrm{H}$ or $\mathrm{L}$ during the second half of gestation are shown in Tables 4-7. 
The feeding of diet $\mathrm{L}$ resulted in a reduction in muscle weight $(P<0.001)$, protein content $(P<0.01)$ and RNA content $(P<0.001)$ by day 1 of lactation. The rates of muscle protein synthesis were also reduced $(P<0.05)$ by the low-protein dietary treatment, with muscle FSR (\% per d) and ASR (mg protein/d) being reduced from $4.4 \%$ per $\mathrm{d}$ and $15.0 \mathrm{mg} / \mathrm{d}$ to $3.4 \%$ per $\mathrm{d}$ and $9.9 \mathrm{mg} / \mathrm{d}$ in groups $\mathrm{H}$ and $\mathrm{L}$ respectively. There was no significant difference in muscle RNA activity between groups $\mathrm{H}$ or $\mathrm{L}$. The reduction in gastrocnemius muscle weight and protein content, by 18 and $16 \%$ respectively, of group $\mathrm{L}$ females reflects the loss of maternal protein reserves, which is also indicated by the reduced carcass protein content of such females (Table 2).

The rate of protein synthesis and tissue composition in the mammary gland, liver and duodenal mucosa on day 1 of lactation were not significantly affected by gestation dietary treatment (Tables 5-7), and this reflects the lack of effect of such dietary treatment on organ size (Table 2). The main effect of the low-protein dietary treatment on the depletion of maternal protein reserves was therefore reflected in muscle protein metabolism.

\section{Effect of gestational dietary treatment on tissue $\mathrm{O}_{2}$ consumption and $\mathrm{Na}^{+}, \mathrm{K}^{+}$-ATPase- dependent respiration}

The $\mathrm{O}_{2}$ consumption and associated $\mathrm{Na}^{+}, \mathrm{K}^{+}$-ATPase activity of the muscle, mammary gland, liver and duodenal mucosa on day 1 of lactation are shown in Tables 4-7.

Dietary protein restriction during the second half of gestation tended to reduce the total, $\mathrm{Na}^{+}, \mathrm{K}^{+}$-ATPase-dependent and independent respiration of the tissues studied by day 1 of lactation, although with the exception of the liver total $\mathrm{O}_{2}$ consumption $(P<0.05)$ these reductions were not statistically significant at the $5 \%$ level.

In gastrocnemius muscle the proportion of $\mathrm{O}_{2}$ consumption inhibition by ouabain $\left(\mathrm{Na}^{+}, \mathrm{K}^{+}\right.$-ATPase-dependent respiration) tended to be lower $(P<0 \cdot 10$ for group $\mathrm{L}$ than for group $\mathrm{H}$ and ranged from $24 \cdot 0-32 \cdot 3 \%$. This proportion in mammary gland, liver and duodenal mucosa ranged from $12 \cdot 5-15 \cdot 7,18 \cdot 9-21 \cdot 1$ and $17 \cdot 6-20 \cdot 3 \%$ respectively.

The effects of gestational and lactational dietary treatments on tissue protein synthesis and $\mathrm{O}_{2}$ consumption on day 13 of lactation

Muscle. The rate of muscle protein synthesis, muscle composition and tissue respiration of the four lactation treatment groups $\mathrm{HH}, \mathrm{LH}, \mathrm{HL}_{2}$ and $\mathrm{LL}_{2}$ on day 13 of lactation are shown in Table 4.

The rate of muscle protein synthesis on day 13 of lactation was influenced solely by the lactational dietary treatment, with both FSR and ASR of groups $\mathrm{HL}_{2}$ and $\mathrm{LL}_{2}$ being lower $(P<0.05)$ than those of the two high-protein groups. The reduced rates of muscle protein synthesis, both FSR and ASR, of group $\mathrm{HL}_{2}$ were also lower $(P<0.05)$ than those of group $H$ on day 1 , being reduced from 4.40 to $3.34 \%$ per $d$ and 15.05 to $8.44 \mathrm{mg} / \mathrm{d}$ respectively. A similar effect was seen for group $\mathrm{LH}$, where feeding of diet $\mathbf{H}$ increased $(P<0.05)$ muscle protein synthesis when compared with that of group $\mathrm{L}$ on day 1 , increasing from 3.40 to $4.84 \%$ per $\mathrm{d}$ and 9.87 to $14.55 \mathrm{mg} / \mathrm{d}$ for FSR and ASR respectively. The rate of muscle protein synthesis in groups $\mathrm{HH}$ and $\mathrm{LL}_{2}$ did not change during lactation.

Dietary protein restriction during lactation reduced $(P<0.05)$ muscle weight, protein and RNA content of groups $\mathrm{HL}_{2}$ and $\mathrm{LL}_{2}$ when compared with those of groups $\mathrm{HH}$ and LH. These reduced muscle protein contents were also lower $(P<0.05)$ than those of groups $\mathrm{H}$ and $\mathrm{L}$ on day 1 of lactation, with muscle protein losses of approximately 93 and $45 \mathrm{mg}$ between days 1 and 13 for $\mathrm{HL}_{2}$ and $\mathrm{LL}_{2}$ respectively. Muscle weight and RNA content of group $\mathrm{HL}_{2}$ were also lower $(P<0.05)$ than those of group $\mathrm{H}$ on day 1 of lactation. The muscle weight and protein content of group LH were lower $(P<0.05)$ than those of group HH on day 13 of lactation and were not significantly greater than values for group $L$ on 


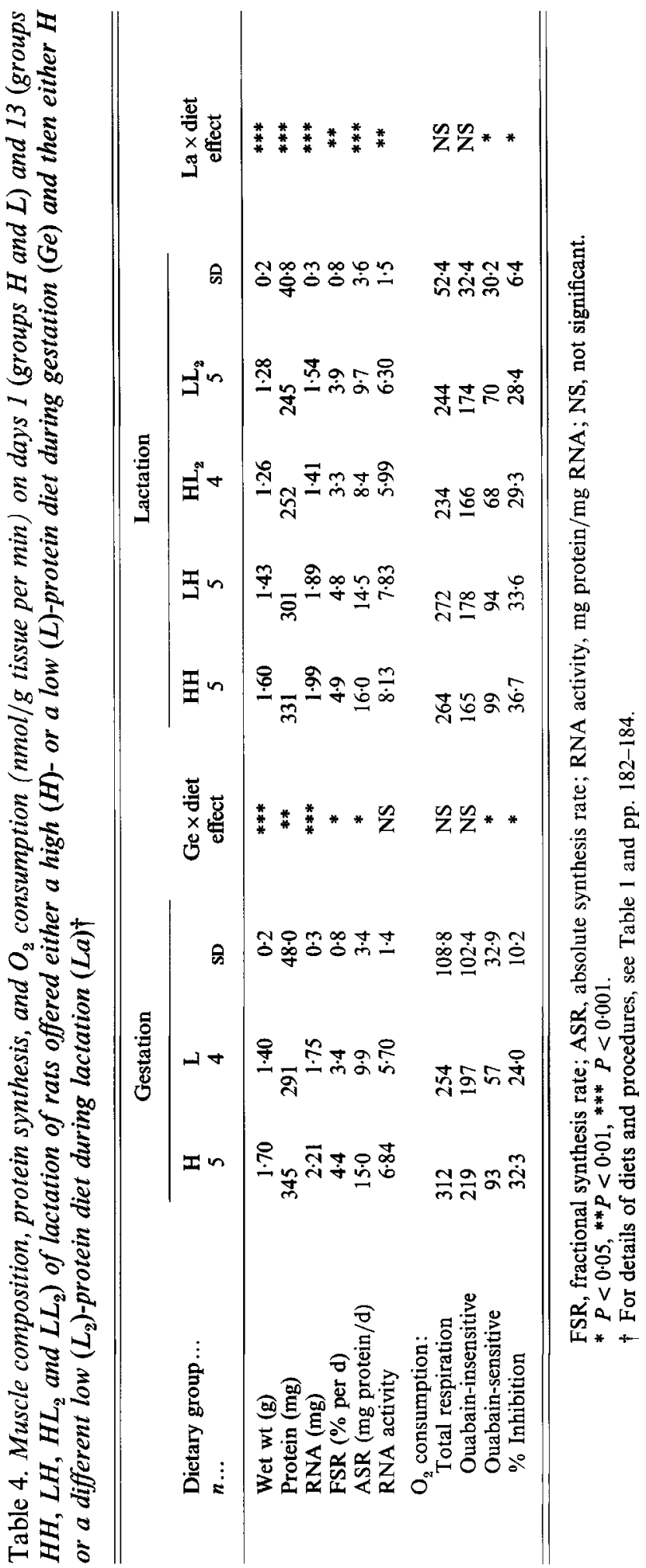


PROTEIN METABOLISM IN LACTATING RATS

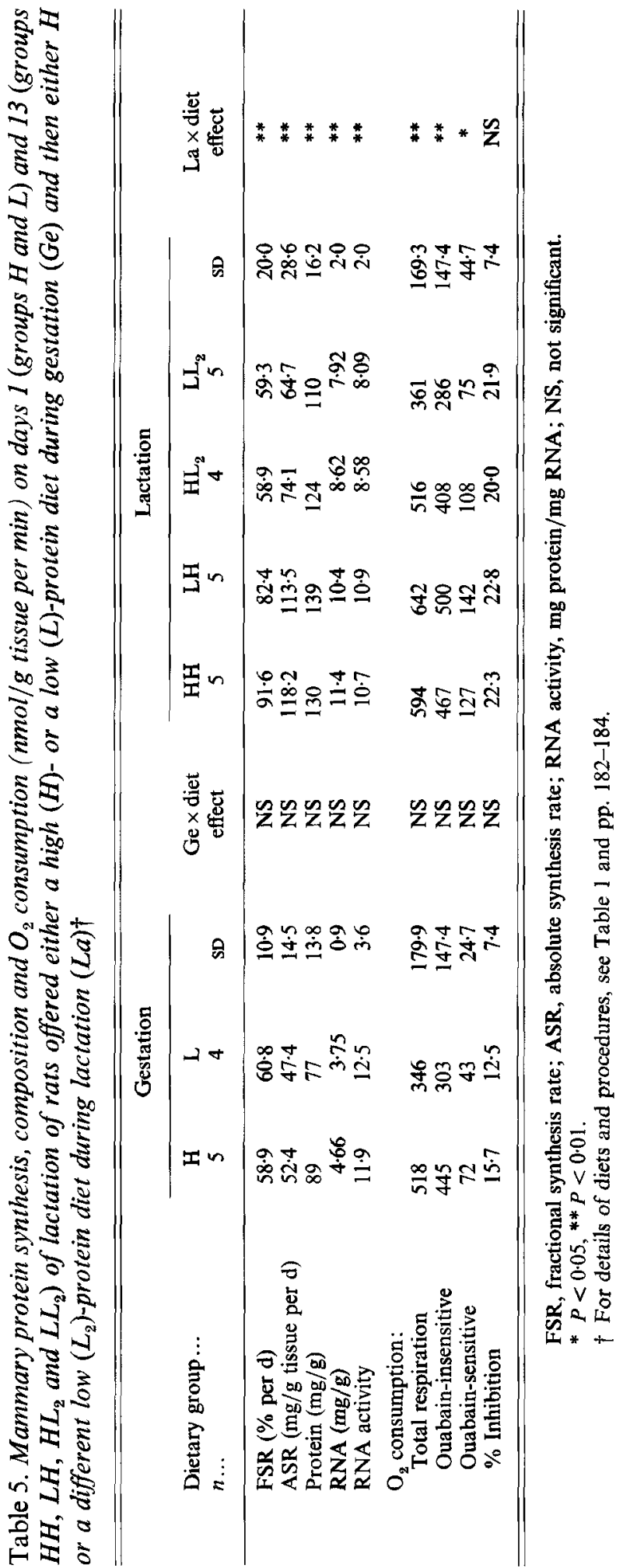


day 1. Group LH were thus unable to replenish their depleted muscle protein when offered the high-protein diet despite the fact that their protein synthetic rate and RNA activity were increased compared with day 1 of lactation. Group $\mathrm{HH}$ showed no change in their muscle protein metabolism or composition compared with group $\mathrm{H}$ on day 1 .

On day 13 of lactation, muscle energy expenditure, represented by total $\mathrm{O}_{2}$ consumption, showed no significant effect of gestation or lactation dietary treatments, although the $\mathrm{O}_{2}$ consumption of the groups offered diet $\mathrm{L}_{2}$ tended to be lower than that of the two highprotein groups (Table 4). This lower muscle $\mathrm{O}_{2}$ consumption by $\mathrm{HL}_{2}$ and $\mathrm{LL}_{2}$ was reflected in a reduced $(P=0.062) \mathrm{Na}^{+}, \mathrm{K}^{+}$-ATPase-dependent respiration compared with that of the groups offered diet $\mathrm{H}$. When these results are presented as the proportion of total $\mathrm{O}_{2}$ consumption (\% inhibition), the proportion associated with $\mathrm{Na}^{+}, \mathrm{K}^{+}$-ATPase activity was lower $(P<0.05)$ in groups $\mathrm{HL}_{2}$ and $\mathrm{LL}_{2}$ when compared with that of group $\mathrm{HH}$. On day 13 of lactation $\mathrm{Na}^{+}, \mathrm{K}^{+}$-ATPase activity accounted for between 28 and $37 \%$ of muscle respiration. There were no significant changes in total muscle respiration between days 1 and 13 of lactation although it can be seen that dietary protein restriction reduced the proportion associated with $\mathrm{Na}^{+}, \mathrm{K}^{+}$-ATPase (Table 4).

Mammary tissue. The rates of mammary protein synthesis, mammary composition and tissue respiration for the four treatment groups $\mathrm{HH}, \mathrm{LH}, \mathrm{HL}_{2}$ and $\mathrm{LL}_{2}$ on day 13 of lactation are shown in Table 5.

Feeding diet $\mathrm{H}$ during lactation promoted an increase $(P<0.05)$ in mammary protein synthesis when compared with that on day 1 of lactation, with FSR increasing from around $59 \%$ per d on day 1 to 92 and $82 \%$ per d on day 13 for groups $\mathrm{HH}$ and LH respectively. Dietary protein restriction during lactation prevented any substantial increase in mammary protein synthesis of groups $\mathrm{HL}_{2}$ and $\mathrm{LL}_{2}$, except for the ASR of $\mathrm{HL}_{2}(P<0.05)$, and resulted in the two low-protein groups having lower $(P<0.01)$ rates of mammary protein synthesis, both FSR and ASR (mg protein/g tissue per d), when compared with those of groups $\mathrm{HH}$ and LH.

Lactation resulted in a change in mammary composition, with the protein and RNA contents $(\mathrm{mg} / \mathrm{g}$ tissue) increasing $(P<0.05)$ in all groups when compared with day 1 , although protein restriction of group $\mathrm{LL}_{2}$ prevented as great an increase as that of groups $\mathrm{HH}$ and LH (Table 5). On day 13 of lactation the protein content, RNA content and activity of the groups offered diet $\mathrm{L}_{2}$ were significantly lower than in those offered the highprotein diet during lactation. The RNA activity of the four treatment groups tended to be lower than that of groups $H$ and $L$ on day 1 , with the reduction in RNA activity of the $\mathrm{LL}_{2}$ group being significant $(P<0.05$; Table 5).

On day 13 of lactation the mammary total, $\mathrm{Na}^{+}, \mathrm{K}^{+}$-ATPase-dependent and -independent respiration rates were not significantly different for groups $\mathrm{HH}, \mathrm{LH}$ and $\mathrm{HL}_{2}$, although diet $\mathrm{L}_{2}$ resulted in groups $\mathrm{LL}_{2}$ having lower $(P<0-05)$ levels of respiration compared with the two high-protein groups. Both low-protein groups showed no significant increase in mammary respiration during lactation. However, the feeding of the high-protein diet during lactation resulted in an increased mammary $\mathrm{O}_{2}$ consumption (Table 5). The increase in total and $\mathrm{Na}^{+}, \mathrm{K}^{+}$-ATPase-independent respiration was significant only for group LH $(P<0.05)$, while the $\mathrm{Na}^{+}, \mathrm{K}^{+}$-ATPase-dependent respiration was significantly increased in both $\mathrm{HH}$ and $\mathrm{LH}$ groups $(P<0.05)$. By day 13 of lactation the proportion of total respiration associated with $\mathrm{Na}^{+}, \mathrm{K}^{+}$-ATPase activity was increased $(P<0.05)$ in both LH and $\mathrm{LL}_{2}$ groups compared with that on day 1 , accounting for between 20 and $23 \%$ of total mammary respiration.

Liver. On day 13 of lactation the gestational and lactational dietary treatments had no significant effect on hepatic protein synthesis, with both liver FSR and ASR (mg protein/g tissue per d) not different for the four lactation treatment groups. These rates were also not significantly different from those on day 1 of lactation (Table 6). 


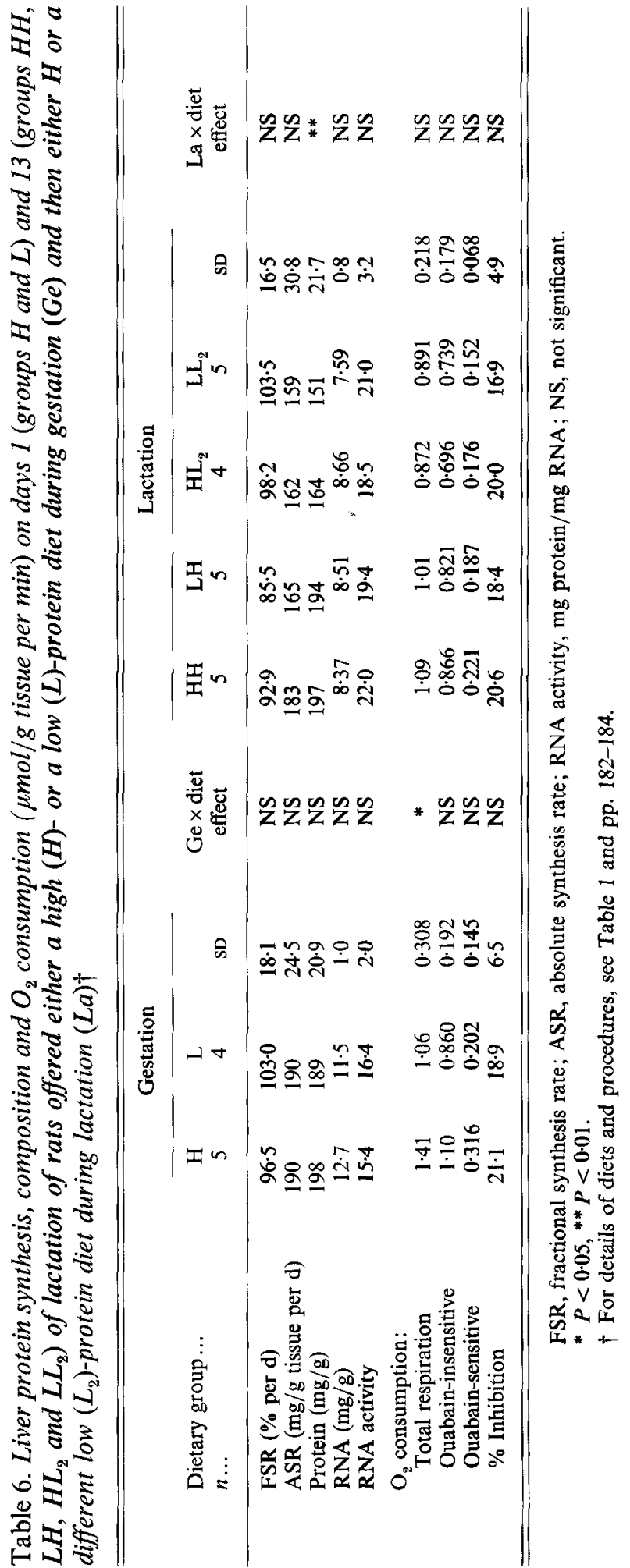







Dietary protein restriction resulted in a loss of liver protein during lactation such that the hepatic protein contents $\left(\mathrm{mg} / \mathrm{g}\right.$ tissue) of groups $\mathrm{HL}_{2}$ and $\mathrm{LL}_{2}$ were lower $(P<0.05)$ than both that on day 1 of lactation (Table 6) and those of groups $\mathrm{HH}$ and $\mathrm{LH}$. The hepatic RNA contents (mg RNA/g tissue) for all lactation groups were lower $(P<0.05)$ than those on day 1 of lactation, although they were not different from each other. Hepatic RNA activities were also not significantly different between the four lactation groups, although the RNA activity of the $\mathrm{HH}$ group was increased compared with day $1(P<0.05$; Table 6).

Hepatic energy expenditure on day 13 of lactation did not differ between the groups and was also not different from that at the start of lactation.

Duodenal mucosa. The rates of protein synthesis and tissue respiration of the duodenal mucosa for the four lactation treatment groups are shown in Table 7.

On day 13 of lactation the rate of mucosal protein synthesis and mucosal protein and RNA contents ( $\mathrm{mg} / \mathrm{g}$ tissue) were not significantly affected by dietary protein level and thus food intake during lactation. Mucosal protein synthesis and composition was also, in general, not significantly altered between days 1 and 13 of lactation (Table 7), although the ASR (mg protein/g tissue per d) of group HH was increased $(P<0.05)$. The RNA activity on day 13 was not significantly affected by dietary protein content during lactation, although again the RNA activity of group $\mathrm{HH}$ was increased compared with day 1 $(P<0 \cdot 05)$.

In a similar way to mucosal protein synthesis, tissue respiration ( $\mathrm{nmol} \mathrm{O}_{2} / \mathrm{mg}$ protein per $\mathrm{min}$ ) on day 13 of lactation was not affected by dietary protein content and did not differ between days 1 and 13 (Table 7). On day 13 of lactation mucosal $\mathrm{Na}^{+}, \mathrm{K}^{+}$-ATPase activity accounted for between 15.5 and $21.5 \%$ of total mucosal energy expenditure, comparable with that of mammary gland and liver (Tables 5 and 6).

\section{DISCUSSION}

Data from this and our earlier study (Pine et al. 1994) have shown that dietary manipulation during gestation leads to differences at parturition in carcass protein content but not in the size of adipose tissue stores, organ weights and composition nor in pup size. Patterns of response in terms of food intake, maternal and litter performance in the present study were similar to those of the earlier study so that extension of the results of these studies to the performance data obtained previously seems reasonable.

The dietary treatments imposed during gestation would appear not to have compromised the ability of females to lactate. In general, rates of protein synthesis, $\mathrm{O}_{2}$ consumption and protein synthetic capacity in mammary tissue, liver and duodenal mucosa were not affected. This is in contrast to the finding of Rosso et al. (1981) who showed that combined protein and energy restriction from the end of the first trimester of gestation in rats resulted in a significant reduction in mammary gland hypertrophy and hyperplasia by day 1 of lactation. In the present study, because of the isoenergetic nature of the diets used, feeding of diet $\mathbf{L}$ during gestation resulted in a restriction in protein supply only, and by day 1 of lactation there was no significant effect on mammary size, composition or rates of protein synthesis and respiration.

During gestation the increase in loss of muscle protein in those animals given diet $\mathrm{L}$ was probably aided by the reduction in muscle protein synthesis (FSR, ASR) that was recorded on day 1 of lactation. However, rates of muscle protein degradation cannot be calculated for day 1 , therefore the possibility that degradation was enhanced cannot be ruled out. Other workers have suggested that such a decline in muscle protein synthesis during the catabolic phase of gestation in protein-restricted female rats may spare amino acids for the developing feto-placental unit (Mayel-Afshar \& Grimble, 1983). Although muscle 
respiration on day 1 was not significantly affected by the gestation treatment, feeding of diet $L$ with the consequent reduction in amino acid intake tended to be associated with reduced $\mathrm{Na}^{+}, \mathrm{K}^{+}$-ATPase activity $(P<0 \cdot 10)$, possibly reflecting the reduced requirement for amino acids by this tissue (Adeola et al. 1989).

The rate of liver protein synthesis (\% per $\mathrm{d}$ ) is not particularly sensitive to reductions in protein quantity and/or quality during lactation (Sampson \& Jansen, 1984 b; Sampson et al. 1986) and the absolute rate (ASR, $\mathrm{mg} / \mathrm{d}$ ) is only reduced following a reduction in liver weight and protein content (Jansen \& Hunsaker, 1986). A similar lack of sensitivity in hepatic protein synthesis to dietary protein restriction during lactation is reported here, with the rate of protein synthesis on day 13 being unchanged from that on day 1 .

Under conditions of adequate nutrition, lactation is normally associated with hypertrophy of the intestines, liver and mammary gland and with an elevation of food intake (Williamson, 1980; Canas et al. 1982). In our previous study gut and liver hypertrophy were seen in rats adequately nourished with a protein-rich food but not when dietary protein content (and food intake) were low (Pine et al. 1994). Applying the liver weights (in parentheses) and protein content, for females slaughtered on day 13 of lactation and offered similar dietary treatments from the earlier study (Pine et al. 1994), rates of liver ASR (mg/d) would have been approximately $4150(22.7 \mathrm{~g}), 3737(22.6 \mathrm{~g}) .2272(14 \cdot 1 \mathrm{~g})$ and $2146 \mathrm{mg} / \mathrm{d}(13.5 \mathrm{~g})$ for groups $\mathrm{HH}, \mathrm{LH}, \mathrm{HL}_{2}$ and $\mathrm{LL}_{2}$ respectively. From these data it is clear that during lactation hypertrophy of the liver would exaggerate the difference in absolute hepatic protein synthesis between the high- and low-protein groups. The loss of liver protein during lactation in response to a reduced dietary protein supply observed here is consistent with previous studies (Jansen \& Hunsaker, 1986; Sainz et al. 1986).

It is generally accepted that the gastrointestinal tract makes a greater contribution to body protein turnover than the liver. In the present study fractional rates of protein synthesis in the duodenal mucosa were between 1.27 and $1.57 \%$ per $d$ and these are close to previously reported values for rat intestinal mucosa (McNurlan et al. 1979). On day 13 of lactation, rates of mucosal protein synthesis were unaffected by dietary treatment. However, the increase in intake of the high-protein diet during lactation would be associated with an increase in the size of intestinal mucosa (Lichtenberger \& Trier, 1979), providing an increased surface area and digestive capacity of the gastrointestinal tract. Total, rather than fractional, protein synthesis associated with the intestinal mucosa would therefore be expected to be considerably increased during lactation, with a sizeable difference between females offered the high- or low-protein diets.

Unlike lactose and lipid production (Williamson et al. 1984), protein synthesis in the mammary gland is not subject to diurnal variation (Sampson \& Jansen 1984a). The timing of the protein synthesis measurement would therefore not have had a dramatic effect on the values obtained in this study. The quantity of dietary protein offered during lactation had a significant impact on the rate of mammary protein synthesis, with both mammary FSR and ASR ( $\mathrm{mg} / \mathrm{g}$ tissue per $\mathrm{d}$ ) in groups $\mathrm{HH}$ and $\mathrm{LH}$ being significantly greater than that of the two low-protein groups and also compared with that on day 1 of lactation. Previous studies have shown a significant effect of protein quantity on mammary protein synthesis in rats, while improvements in protein quality at a similar level of protein quantity have a more dramatic effect (Jansen \& Hunsaker, 1986; Sampson et al. 1986). Using mammary weights (in parentheses) from a previous experiment (Pine et al. 1994), for females slaughtered on day 13 of lactation in groups HH and LH the total rate of protein synthesis would have been $2960(25.0 \mathrm{~g})$ and $3178 \mathrm{mg} / \mathrm{d}(28.0 \mathrm{~g})$ respectively. For all groups, mammary ASR was strongly correlated with daily litter weight gain on day 12 of lactation $\left(r^{2} 0.61, P<0.001\right)$.

The maintenance of tissue protein turnover is supported by a variety of cellular 
mechanisms, one of which is the membrane transport system $\mathrm{Na}^{+}, \mathrm{K}^{+}$-ATPase which plays an essential role in the transport of amino acids and sugars across cell membranes. $\mathrm{Na}^{+}, \mathrm{K}^{+}$. ATPase activity accounts for a major part of cellular energy expenditure and on day 13 of lactation in the present study represented $28-37,20-23,17-21$ and $16-22 \%$ of tissue respiration in the gastrocnemius muscle, mammary gland, liver and duodenal mucosa respectively.

The proportion of tissue energy expenditure associated with $\mathrm{Na}^{+}, \mathrm{K}^{+}$-ATPase activity has been reported to be significantly increased during lactation in the intestinal mucosa of cows from $35 \%$ (dry) to $54 \%$ (peak) and liver of sheep from $37 \%$ (dry) to $45 \%$ (peak yield; McBride \& Milligan, 1984, 1985a). The results of the present study do not support this, with tissue respiration and the proportion associated with $\mathrm{Na}^{+}, \mathrm{K}^{+}$-ATPase activity in the liver and mucosa on the whole remaining unchanged between days 1 and 13 of lactation. It should be noted that although the rates of tissue respiration per gram were unchanged, the organ hypertrophy associated with lactation would result in a considerable increase in total and $\mathrm{Na}^{+}, \mathrm{K}^{+}$-ATPase-dependent energy expenditure in tissues such as the liver and gut. The $\mathrm{Na}^{+}, \mathrm{K}^{+}$-ATPase activity in the mammary gland was significantly increased during lactation in the groups offered diet $\mathrm{H}$, and this reflects the increased metabolic activity and protein synthesis in this tissue.

The proportions of tissue respiration associated with $\mathrm{Na}^{+}, \mathrm{K}^{+}$-ATPase activity in liver and duodenal mucosa (approximately $20 \%$ ) were considerably lower than other published data for the liver (37-45\%) and mucosa (28-61\%); McBride \& Milligan 1985a,b). The lower contribution of $\mathrm{Na}^{+}, \mathrm{K}^{+}$-ATPase activity to tissue respiration reported here may be attributed to differences in the incubation medium used between these studies (Milligan \& Summers, 1986; Jessop, 1988).

Dietary protein restriction during gestation and lactation significantly reduced the rate of muscle protein synthesis of days 1 and 13 of lactation and ultimately promoted a loss in muscle weight and protein content. Rates of muscle protein synthesis have been closely linked with the activity of $\mathrm{Na}^{+}, \mathrm{K}^{+}$-ATPase (Vandenburgh \& Kaufman, 1981; Adeola et al. 1989 ) and protein restriction during lactation significantly reduced the proportion of tissue respiration associated with this enzyme. Muscle protein synthesis $(\mathrm{mg} / \mathrm{d})$ and $\mathrm{Na}^{+}, \mathrm{K}^{+}$ATPase activity (nmol $\left.\mathrm{O}_{2} / \mathrm{d}\right)$ were highly correlated $\left(r^{2} 0.48 ; P<0.001 ; n 29\right)$, with no evidence to suggest a departure from this correlation in animals given the low-protein diets.

Estimations of the contribution that $\mathrm{Na}^{+}, \mathrm{K}^{+}$-ATPase activity makes to muscle total respiration vary between studies, being 22-25\% in growing pigs (Adeola et al. 1989), $40 \%$ in growing calves (Gregg \& Milligan, 1982 b) and 42-46\% in dry and lactating ewes respectively (Gregg \& Milligan 1982c). These compare with $24-32 \%$ and $28-37 \%$ on days 1 and 13 of lactation respectively in the present study and further reflect the importance of this enzyme in muscle energy expenditure.

Assuming that both FSR changes and the loss of muscle protein during lactation occur at a steady, linear rate between days 1 and 13 of lactation, then the average rate of protein degradation (FDR) during lactation was 5.01, 3.81, 6.45 and 4.76\% per $\mathrm{d}$ for groups $\mathrm{HH}$, $\mathrm{LH}, \mathrm{HL}_{2}$, and $\mathrm{LL}_{2}$ respectively. Whether these assumptions are realistic or not cannot be tested from these data but they seem to be reasonable. The calculated rates of protein degradation for the different treatments would suggest that both changes in muscle protein synthesis and degradation play a part in regulating the use of maternal protein, an observation which contrasts somewhat with the results from other studies concerning lactating animals in which increases solely in rates of degradation (Bryant \& Smith, 1982) or decreases solely in rates of synthesis (Swick \& Benevenga, 1977) have been reported.

It is possible that this calculation of FDR may have underestimated the true degradation rate since from earlier studies it has been suggested that the mobilization of maternal 
protein occurs predominantly during the first half of lactation (Pine et al. 1994). The measurements made in the present study cannot detect such changes in protein turnover occurring during early lactation and thus further work on protein loss during this period is required.

Results of a previous study suggested that during lactation improvements in dietary protein supply to females previously protein-depleted allowed them to achieve a lactational performance similar to that of other females offered the same diet, while at the same time attempting to replenish their depleted reserves (Pine et al. 1994). In this current study the LH group showed a significantly increased rate of muscle protein synthesis $(3.4$ $4.8 \%$ per d) and RNA activity during lactation, and this could represent part of the mechanism involved in protein replenishment.

In summary, the results of these studies show that the reduced milk secretion consequent on protein undernutrition is reflected in an impaired mammary protein metabolism, although other tissues appear to be less sensitive to reductions in protein supply during lactation. The mobilization of maternal protein reserves during lactation involves changes in both muscle protein synthesis and degradation. The reduction in muscle protein synthesis is also associated with reduced activity of the $\mathrm{Na}^{+}, \mathrm{K}^{+}$-ATPase enzyme.

APP gratefully acknowledges receipt of an Agricultural and Food Research Council studentship. Statistical advice from Dr G. W. Horgan, Scottish Agricultural Statistics Service is gratefully acknowledged. We are grateful to Dr Peter Garlick for helpful advice in the application of the ${ }^{3} \mathrm{H}$-phenylalanine flood dose method.

\section{REFERENCES}

Adeola, O., Young, L. G., McBride, B. W. \& Ball, R. O. (1989). In vitro $\mathrm{Na}^{+}, \mathrm{K}^{+}$-ATPase (EC 3.6.1.3)dependent respiration and protein synthesis in skeletal muscle of pigs fed at three dietary protein levels. British Journal of Nutrition 61, 453-465.

Albers, R. W., Kovala, G. J. \& Siegel, C. J. (1968). Studies on the interaction of ouabain and other active steroids with sodium potassium activated adenosine triphosphatase. Molecular Pharmacology 4, 324-336.

Ashford, A. J. \& Pain, V. M. (1986). Effect of diabetes on the rates of synthesis and degradation of ribosomes in rat muscle and liver in vivo. Journal of Biological Chemistry 261, 4059-4065.

Baracos, V. E., Brun-Bellut, J. \& Marie, M. (1991). Tissue protein synthesis in lactating and dry goats. British Journal of Nutrition 66, 451-465.

Bartley, J. C. \& Abraham, S. (1976). The absolute rate of fatty acid synthesis by mammary gland slices from lactating rats. Journal of Lipid Research 17, 467-477.

Bryant, D. T. W. \& Smith, R. W. (1982). The effect of lactation on protein synthesis in ovine skeletal muscle. Journal of Agricultural Science, Cambridge 99, 319-323.

Canas, R., Romero, J. J. \& Baldwin, R. L. (1982). Maintenance energy requirements during lactation in rats. Journal of Nutrition 112, 1876-1880.

Friggens, N. C., Hay, D. E. F. \& Oldham, J. D. (1993). Interactions between major nutrients in the diet and the lactational performance of rats. British Journal of Nutrition 69, 59-71.

Garlick, P. J., Fern, M. \& Preedy, V. R. (1983). The effect of insulin infusion and food intake on muscle protein synthesis in post absorptive rats. Biochemical Journal 210, 669-676.

Garlick, P. J., McNurlan, M. A. \& Preedy, V. R. (1980). A rapid and convenient technique for measuring the rate of protein synthesis in tissues by the injection of $\left.{ }^{3} \mathrm{H}\right]$ phenylalanine. Biochemical Journal 192, 719-723.

Gregg, V. A. \& Milligan, L. P. (1982a). Role of $\mathrm{Na}^{+}, \mathrm{K}^{+}$-ATPase in muscular energy expenditure of warm- and cold-exposed sheep. Canadian Journal of Animal Science 62, 123-132.

Gregg, V. A. \& Milligan, L. P. (1982b). In vitro energy costs of $\mathrm{Na}^{+}, \mathrm{K}^{+}$-ATPase activity and protein synthesis from calves differing in age and breed. British Journal of Nutrition 48, 65-71.

Gregg, V. A. \& Milligan, L. P. $(1982 c)$. $\mathrm{O}_{2}$ consumption and $\mathrm{Na}^{+}, \mathrm{K}^{+}$-ATPase dependent respiration in muscle of lambs and lactating and non lactating ewes. In Energy Metabolism of Farm Animals, pp. 66-69 [A. Ekern and F. Sundstol, editors]. Aas, Norway: Agricultural University of Norway.

Jansen, G. R. \& Hunsaker, H. (1986). Effect of dietary protein and energy on protein synthesis during lactation in rats. Journal of Nutrition 116, 957-968.

Jessop, N. S. (1988). Estimation of energy expenditure associated with $\mathrm{Na}^{+}, \mathrm{K}^{+}-\mathrm{ATPase}$ activity in ovine liver. Proceedings of the Nutrition Society 47, 118A. 
Lichtenberger, L. M. \& Trier, J. S. (1979). Changes in gastrin levels, food intake and duodenal mucosal growth during lactation. American Journal of Physiology 237, E98-E105.

Lowry, O. H., Rosebrough, N. J., Farr, A. L. \& Randall, R. J. (1951). Protein measurement with the Folin phenol reagent. Journal of Biological Chemistry 193, 265-275.

McBride, B. W. \& Milligan, L. P. (1984). The effect of lactation on ouabain sensitive respiration of the duodenal mucosa of cows. Canadian Journal of Animal Science 64, 817-824.

McBride, B. W. \& Milligan, L. P. (1985a). Magnitude of ouabain-sensitive respiration in the liver of growing and lactating sheep. British Journal of Nutrition 54, 293-303.

McBride, B. W. \& Milligan, L. P. (1985b). Influence of food intake and starvation on the magnitude of $\mathrm{Na}^{+}, \mathrm{K}^{+}-$ ATPase (EC 3.6.1.3)-dependent respiration in duodenal mucosa of sheep. British Journal of Nutrition $\mathbf{5 3}$, 605-614.

McNurlan, M. A., Tomkins, A. M. \& Garlick, P. J. (1979). The effect of starvation on the rate of protein synthesis in the rat liver and small intestine. Biochemical Journal 178, 373-379.

Mahan, D. C. \& Mangan, L. T. (1975). Evaluation of various protein sequences on the nutritional carry over from gestation to lactation with first litter sows. Journal of Nutrition 105, 1291-1298.

Mayel-Afshar, S. \& Gimble, R. F. (1983). Changes in protein turnover during gestation in the foetus, placenta, liver, muscle and whole body of rats given a low protein diet. Biochimica et Biophysica Acta 756, $182-190$.

Millican, P. E., Vernon, R. G. \& Pain, V. M. (1987). Protein metabolism in the mouse during pregnancy and lactation. Biochemical Journal 248, 251-257.

Milligan, L. P. \& Summers, M. (1986). The biological basis of maintenance and its relevance to assessing responses to nutrients. Proceedings of the Nutrition Society 45, $185-193$.

Munro, H. N. \& Fleck A. (1969). Analysis of tissues and body fluids for nitrogenous constituents. In Mammalian Protein Metabolism, vol. 3, pp 425-465 [H. N. Munro, editor]. New York: Academic Press.

National Research Council (1978). Nutrient Requirements of Laboratory Animals, 3rd ed. Washington, DC: National Academy of Sciences.

Pine, A. P., Jessop, N. S. \& Oldham, J. D. (1994). Maternal protein reserves and their influence on lactational performance in rats. British Journal of Nutrition 71, 13-27.

Rosso, P., Keyou, G., Bassi, J. A. \& Slusser, W. M. (1981). Effect of malnutrition during pregnancy on the development of the mammary glands of rats. Journal of Nutrition 111, 1937-1941.

Sainz, R. D., Calvert, C. C. \& Baldwin, R. L. (1986). Relationships among dietary protein, food intake and tissue protein turnover in lactating rats. Journal of Nutrition 116, 1820-1829.

Sampson, D. A., Hunsaker, H. A. \& Jansen, G. R. (1986). Dietary protein quality, protein quantity and food intake: effects on lactation and on protein synthesis and tissue composition in mammary tissue and liver of rats. Journal of Nutrition 116, 365-375.

Sampson, D. A. \& Jansen, G. R. (1984a). Protein and energy nutrition during lactation. Annual Review of Nutrition 4, 43-67.

Sampson, D. A. \& Jansen, G. R. (1984b). Protein synthesis during lactation: no circadian variation in mammary gland and liver of rats fed diets varying in protein quality and level of intake. Journal of Nutrition 114, $1470-1478$.

Siebrits, F., Martinez, J. A. \& Buttery, P. J. (1985). The effect of lactation on the fractional synthetic rate of protein in the liver and muscle of rats. International Journal of Biochemistry 17, 731-732.

Swick, R. W. \& Benevenga, N. J. (1977). Labile protein reserves and protein turnover. Journal of Dairy Science 60, 505-515.

Vandenburgh, H. H. \& Kaufman, S. (1981). Stretch induced growth of skeletal myotubes correlates with activation of the sodium pump. Journal of Cellular Physiology 109, 205-214.

Vincent, R. \& Lindsay, D. B. (1985). Effect of pregnancy and lactation on muscle protein metabolism in sheep. Proceedings of the Nutrition Society 44, 77A.

Waterlow, J. C., Garlick, P. J. \& Millward, D. J. (1978). In Protein Turnover in Mammalian Tissues and in the Whole Body, pp. 627-631. New York: North-Holland.

Williamson, D. H. (1980). Integration of metabolism in tissues of the lactating rat. FEBS Letters, 117(Suppl. 1), K93-K 105.

Williamson, D. H., Munday, M. R. \& Jones, R. G. (1984). Biochemical basis of dietary influences on the synthesis of the macro nutrients of rat milk. Federation Proceedings 43, 2443-2447. 